\title{
OPEM
}

www.opem.org

Oriental Pharmacy and Experimental Medicine 2008 7(5), 459-465

DOI 10.3742/OPEM.2008.7.5.459

\section{Effect of Neem (Azadirachta indica) oil on the progressive growth of a spontaneous $\mathbf{T}$ cell lymphoma}

\author{
Sanjaya Kumar Mallick, Vivekanand Gupta, Mahendra Pal Singh, Naveen Kumar Vishvakarma, Nisha \\ Singh and Sukh Mahendra Singh*
}

School of Biotechnology, Banaras Hindu University, Varanasi-221 005, U.P, India

\begin{abstract}
SUMMARY
The present study was undertaken to investigate the effect of in vivo administration of neem oil intra-peritoneally (i.p.) to mice bearing a progressively growing transplantable $\mathrm{T}$ cell lymphoma of spontaneous origin, designated as Daltons lymphoma (DL), on the tumor growth. Mice were administered various doses of neem oil mixed in groundnut oil, which was used as a diluting vehicle or for administration to control DL-bearing mice. Administration of neem oil resulted in an acceleration of tumor growth along with a reduction in the survival time of the tumor-bearing host. Neem oil administered DL-bearing mice showed an augmented apoptosis in splenocytes, bone marrow cells and thymocytes along with an inhibition in the anti-tumor functions of tumorassociated macrophages. Thus this study gives an altogether a novel information that neem oil instead of the popular belief of being anti-tumor and immunoaugmentary may in some tumorbearing conditions, behave in an opposite way leading to an accelarated tumor progression along with a collapse of the host's anti-tumor machinery. These observations will thus have long lasting clinical significance, suggesting caution in use of neem oil for treatment of cancer.
\end{abstract}

Key words: Neem oil; Tumor growth; Tumor-associated macrophages

\section{INTRODUCTION}

Herbal drugs with immunomodulatory properties are being evaluated for their possible anticancer activity. These drugs act by reversing the immunosuppression induced by cancer growth (Singh et al., 2005a,b, 2006). However, different type of tumors shows different responses to anticancer drugs. Therefore, an understanding for mechanism of immunosuppression, with respect to each individual tumor clone and the effect of various immunomodulatory drugs is essential for

\footnotetext{
*Correspondence: Sukh Mahendra Singh, School of Biotechnology, Banaras Hindu University, Varanasi-221 005, U.P, India. Tel: +915422317531; Fax: +915422368693; E-mail: sukhmahendrasingh@yahoo.com
}

a successful implementation of immunotherapeutic protocol. Considering the importance to study the effect of such drugs on tumors of spontaneous origin, we have been investigating the effect of progressive in vivo growth of a murine transplantable T-cell lymphoma designated as Daltons Lymphoma (DL) (Klein, 1951) on the immune status of tumor bearing host. DL growth has been shown to result in a massive suppression of cellular and humoral immune responses and hematopoiesis in the tumor-bearing mice (Bharti and Singh, 2000, 2001, 2003). Further it was demonstrated that extract prepared from herb called Tinospora cordifolia could modulate DL growth through its direct antitumor activity and through its up-regulating effect on the antitumor activity of tumor associated macrophages 
and hematopoiesis in the tumor-bearing host (Singh et al., 2004, 2005a,b, 2006). However, it remains unclear if DL growth and associated antitumor immunity also responds to other herbal preparations.

Neem (Azadirachta indica) has been shown to posses many curative properties in traditional medicine and its several medical applications are well recognized. The activity of neem with the crude extracts, their different fractions and active components have been studied (Koul et al., 2004). Neem oil has been shown to possess immunomodulatory properites (Upadhyay et al., 1992) and polysaccharides isolated from neem bark have shown to inhibit the growth of sarcoma 180 (Fujiwara et al., 1982). However, it remains unclear if products derived from neem oil can also alter the growth of a T-cell lymphoma and related antitumor immunity.

In view of the above observations the present investigation was carried out to study the effect of neem oil on the progression of DL and the related immunological consequences in the mice

\section{MATERIALS AND METHODS}

\section{Mice, tumor system and cell lines}

Pathogen-free inbred adult male and female mice of BALB/c $\left(\mathrm{H}-2^{\mathrm{d}}\right)$ strain were used at $8-12 \mathrm{w}$ of age. The mice received food and water ad libitum and were treated with utmost human care in an approved and certified animal room facility of the Banaras Hindu University at the Institute of Medical Sciences. For all purposes mice were killed by cervical dislocation. DL is maintained in ascitic form by serial transplantation in BALB/c mice or in an in vitro cell culture system by serial passage as described earlier (Bharti and Singh, 2003). Irrespective of whether the DL cells were obtained from the in vitro culture system maintained as suspension cultures or from the ascitic fluid they exhibited similar phenotypic features. A stock of DL cells is also maintained in a cryopreserved state for reference purpose. In all the experiments, the cells obtained from the ascitic fluid, where the yield of DL cells is highest, were used. Serial passaging of DL in mice was carried out by transplanting $1 \times 10^{5} \mathrm{DL}$ cells mouse ${ }^{-1}$, in $0.5 \mathrm{ml}$ phosphate buffered saline (PBS). Mice thus transplanted with DL cells survive for an average of $20 \pm 2$ days. L929, a TNF-sensitive murine fibroblast cell line, was obtained from National Center for Cell Science (Pune, India) and was maintained in the laboratory, for bioassay of tumor necrosis factor (TNF), by serial passaging in culture. $0.25 \%(\mathrm{w} / \mathrm{v})$ solution of trypsin in PBS containing $1 \mathrm{mM}$ EDTA was used for trypsinization of adherent L929 cells. All the cell cultures were maintained in a $\mathrm{CO}_{2}$ incubator with humidified atmosphere containing a mixture of $95 \%$ air and $5 \% \mathrm{CO}_{2}$.

\section{Reagents}

All tissue culture plastics-wares were purchased from Tarsons (India). Tissue culture medium RPMI 1,640 was purchased from Hyclone (Logan, Utah). Commercially available preparation of neem oil was purchased from Baidyanath, Allahabad, India. All other reagents and antibiotics were purchased from Himedia (Bombay) unless mentioned otherwise. Culture media was supplemented with $20 \mu \mathrm{g} / \mathrm{ml}$ gentamycin, $100 \mu \mathrm{g} / \mathrm{ml}$ streptomycin, $100 \mathrm{IU}$ penicillin purchased from and $10 \%$ fetal calf serum from Hyclone (Logan, Utah), henceforth, referred as complete medium, medium without serum was designated as incomplete medium. All the reagents used in the experiments were determined to be endotoxin-free by Limulus Amoebocyte lysate assay (sensitivity limit: $0.1 \mathrm{ng} \mathrm{ml}^{-1}$ ).

\section{Isolation of tumor-associated macrophages (TAM)} Mice, with or without DL, were killed by cervical dislocation and peritoneal exudate cells (PEC) were harvested by peritoneal lavage as described earlier (Singh et al., 2005c). The PEC were cultured in plastic tissue culture flasks (Greiner, Germany) 
at $37^{\circ} \mathrm{C}$ in a $\mathrm{CO}_{2}$ incubator for $2 \mathrm{~h}$. The cultures were then washed thrice with warm serum-free medium with gentle flushing to ensure that all the DL and/or other non-adherent cells were removed. Approximately $95 \%$ of the adherent cell population was macrophages as determined by morphology. The TAM were detached from the tissue Culture flask with a cell scraper and plated in a 96 well flat bottom culture plate $\left(1.5 \times 10^{5}\right.$ cells/well).

\section{Study of tumor progression and survival of tumor bearing mice}

Tumor growth was monitored by measuring increase of the body weight and enumeration of tumor cells in the ascitic fliud of control and experimental groups of DL-bearing mice, upto day 21 following a method described earlier (Singh et $a l ., 2005 c, d)$. The percent increase in body weight was calculated as follows:

Increase in body weight $(\%)=\left(\mathrm{W}_{\mathrm{f}}-\mathrm{W}_{\mathrm{i}}\right) / \mathrm{W}_{\mathrm{f}} \times 100$

Where, $\mathrm{W}_{\mathrm{f}}=$ Weight of mice on day 21 of tumor transplantation; $\mathrm{W}_{\mathrm{i}}=$ Weight of mice on day 1 of tumor transplantation.

DL-bearing control or experimental mice were allowed to live under normal conditions until death. The day of death in each case was noted and the results were shown as percent survival on a standard Kaplan Meier plot (Singh et al., 2005c,d).

\section{Estimation of tumor cell survival in vitro by MTT assay}

Tumor cell survival was assayed according to a method described earlier (Singh et al., 2005a). DL cells were seeded $\left(1.5 \times 10^{5}\right.$ viable cells well $\left.{ }^{-1}\right)$, in a 96 well tissue culture plate in culture conditions mentioned in the results section for $72 \mathrm{~h}$. Cell survival was measured by MTT assay following a method described by Mosmann (1983) with slight modifications. MTT was dissolved in PBS at a concentration of $5.0 \mathrm{mg} / \mathrm{ml}$. Fifty $\mu \mathrm{l}$ of MTT solution was added to each well of the culture plate containing $200 \mu \mathrm{l}$ medium and incubated at $37^{\circ} \mathrm{C}$ for $4 \mathrm{~h}$. The plate was then centrifuged at $100 \times \mathrm{g}$ for $5 \mathrm{~min}$ at $4^{\circ} \mathrm{C}$ (Remi, New Delhi, India). The supernatant was then carefully removed without disturbing the dark blue formazan crystals. One hundred $\mu \mathrm{l}$ of the DMSO was added to each well and mixed thoroughly to dissolve the formazan crystals. The plates were then read on a microplate reader (Labsystems, Helsinki, Finland) at a wavelength of $540 \mathrm{~nm}$. Readings are presented as absorbance at $540 \mathrm{~nm}$.

\section{Assay of TNF activity}

The activity of TNF in the culture supernatant of TAM was measured by dye uptake assay as described earlier (Singh et al., 2006a). Briefly, $3 \times 10^{4}$ L929 cells, in $100 \mu$ l medium were grown in wells of a 96 well tissue culture plate in the presence of $1 \mu \mathrm{g} / \mathrm{ml}$ of Actinomycin-D and $100 \mu \mathrm{l}$ of the test culture supernatant. After $18 \mathrm{~h}$ of incubation the plates were washed and cell lysis was determined by staining the plate with a $0.5 \%(\mathrm{w} / \mathrm{v})$ solution of crystal violet in methanol/water $(1: 4 \mathrm{v} / \mathrm{v})$. The OD was measured at $540 \mathrm{~nm}$.\% Cytotoxicity was calculated as follows:

$\%$ Cytotoxicity $=(\mathrm{C}-\mathrm{T}) / \mathrm{C} \times 100$

Where C is the absorbance of wells containing L929 cells incubated in medium alone, and $\mathrm{T}$ is that of those wells in which L929 cells were incubated with culture supernatant of TAM.

\section{Percent DNA fragmentation}

Induction of apoptotic mode of cells death in cells was also confirmed by quantitative determination of DNA fragmentation following a method given by Sellins and Cohen (1987) with slight modifications (Singh et al., 2006b). Cells $\left(1.5 \times 10^{6}\right.$ cells $\left.\mathrm{ml}^{-1}\right)$ were lysed in $0.5 \mathrm{ml}$ of Tris-EDTA buffer, $\mathrm{pH} 7.4$, containing $0.2 \%(\mathrm{v} / \mathrm{v})$ Triton X-100 and the fragmented DNA was separated from intact chromatin in a microfuge tube (labeled as B) by centrifugation at 
$13,000 \times \mathrm{g}$ at $4^{\circ} \mathrm{C}$ for $10 \mathrm{~min}$. Supernatant containing the fragmented DNA was transferred to another microfuge tube (labeled as T). A volume of $0.5 \mathrm{ml}$ of $25 \%$ TCA was added to each T and B tube and vortexed vigorously. DNA was precipitated overnight at $4^{\circ} \mathrm{C}$ and collected at $13,000 \times \mathrm{g}$ at $4^{\circ} \mathrm{C}$ for $10 \mathrm{~min}$. Supernatant was discarded and $80 \mu \mathrm{l}$ of $5 \%$ TCA was added to each pellet. DNA was hydrolyzed by heating at $90^{\circ} \mathrm{C}$ for $15 \mathrm{~min}$. At this stage a blank was included containing $80 \mu \mathrm{l}$ of $5 \%$ TCA. Then $160 \mu \mathrm{l}$ of freshly prepared diphenylamine (DPA) reagent $(150 \mathrm{mg}$ diphenyleamine in $10 \mathrm{ml}$ glacial acetic acid, $150 \mu \mathrm{l}$ concentrated $\mathrm{H}_{2} \mathrm{SO}_{4}$ and $50 \mu$ of acetaldehyde solution) was added and the tubes were allowed to stand overnight at room temperature to develop color. One hundered $\mu \mathrm{l}$ of this colored solution was transferred to the wells of a 96-well flat-bottomed ELISA plate and absorbance was measured at $600 \mathrm{~nm}$ in a microtitre ELISA plate reader (Labsystems, Finland). Percent DNA fragmentation was calculated as:

DNA fragmentation $(\%)=[\mathrm{T} /(\mathrm{T}+\mathrm{B})] \times 100$

Where $\mathrm{T}=$ absorbance of fragmented DNA and $\mathrm{T}$ $+\mathrm{B}=$ absorbance of total DNA.

\section{Statistical analysis}

The statistical significance of the difference between the test groups was analyzed by the Student's $t$-test (two tailed). The difference was considered significant when the $P$ value was less than 0.05 . All the experiments were done in triplicate and repeated at least three times.

\section{RESULTS}

\section{Effect of neem oil on progression of DL in vivo}

In the first part of experiment the effect of in vivo administration of neem oil on DL progression was investigated. Neem oil was administered i.p. to DL-bearing mice after 2 days of DL transplantation at doses of 100, 300 and $500 \mathrm{mg} / \mathrm{kg}$ body weight

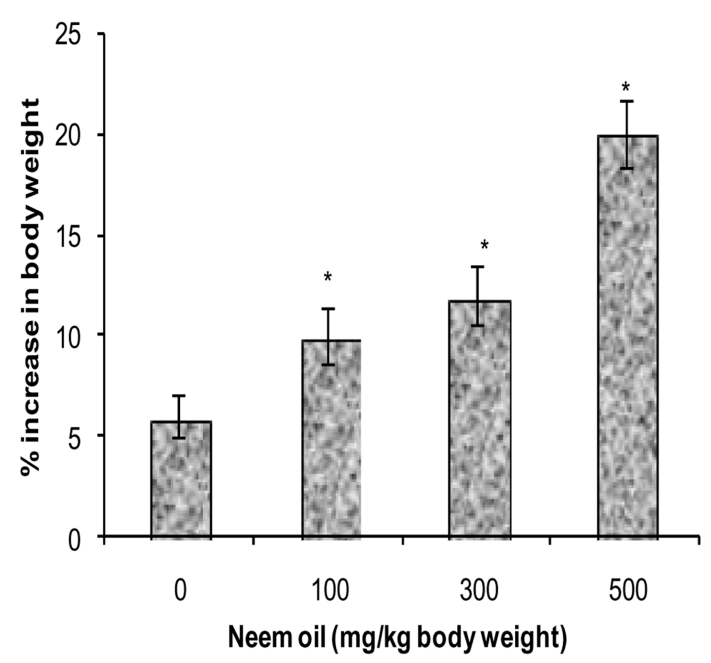

Fig. 1. Effect of neem oil on DL growth in vivo. Mice were treated with neem oil (vehicle alone or neem oil at doses of 100, 300 and $500 \mathrm{mg} / \mathrm{kg}$ body weight) or vehicle alone $48 \mathrm{~h}$ post DL-transplantation on every alternate day for 10 days. Body weight of DL-bearing mice was monitored from day one of tumor transplantation till the day of death and percent increase in body weight was calculated. Values are mean of three independent experiments done in triplicate and are expressed as mean \pm S.D. ${ }^{*} P<0.05$ Vs values for vehicle treated DL-bearing mice.

and progression of tumor growth was monitored by taking the body weight of DL-bearing mice on a daily basis. The percent increase in body weight of DL-bearing mice was found to significantly increase upon administration of neem oil in a dose dependent manner (Fig. 1) as compared to DL-bearing mice administered with vehicle, groundnut oil.

\section{Effect of neem oil on the survival of DL-bearing mice}

The effect of i.p. administration of neem oil on the survival of DL-bearing mice was also investigated. The survival of DL-bearing mice upon administration of neem oil $(300 \mathrm{mg} / \mathrm{kg})$ was found to decrease as compared to the group treated with vehicle alone (Fig. 2). Administration of neem oil at same doses for a similar period of time to normal mice did not decrease the survival of these mice (data not shown). 


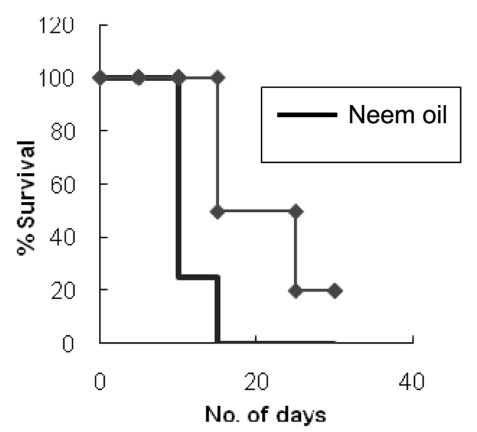

Fig 2. Effect of neem oil administration on survival of tum or-bearing mice.

Fig. 2. Effect of neem oil on the survival of DL-bearing mice. Survival of DL-bearing mice treated with neem oil $(200 \mathrm{mg} / \mathrm{kg})$ or vehicle was measured by monitoring the life span of DL-bearing mice post DL transplantation and plotted in a Kaplan Meier plot. Values are mean of three independent experiments done in triplicate and are expressed as means \pm S.D.

Effect of neem oil on the DNA fragmentation of BMC, splenocytes and thymocytes

We also studied the percent DNA fragmentation of $\mathrm{BMC}$, thymocytes and splenocytes obtained from DL-bearing or normal mice treated with neem oil or vehicle. Results are shown in Table 1. BMC, thymocytes and splenocytes from neem oil-treated mice showed a significantly higher DNA fragmentation as compared to vehicle treated group.

Effect of neem oil on TNF production by tumor associated macrophages

TNF produced by TAM obtained from DL-bearing mice treated with different doses of neem oil was studied in Fig. 3. TNF production was found to remain comparable between the vehicle or neem oil administrated mice. However, TNF production was found to significantly get inhibited at a dose of

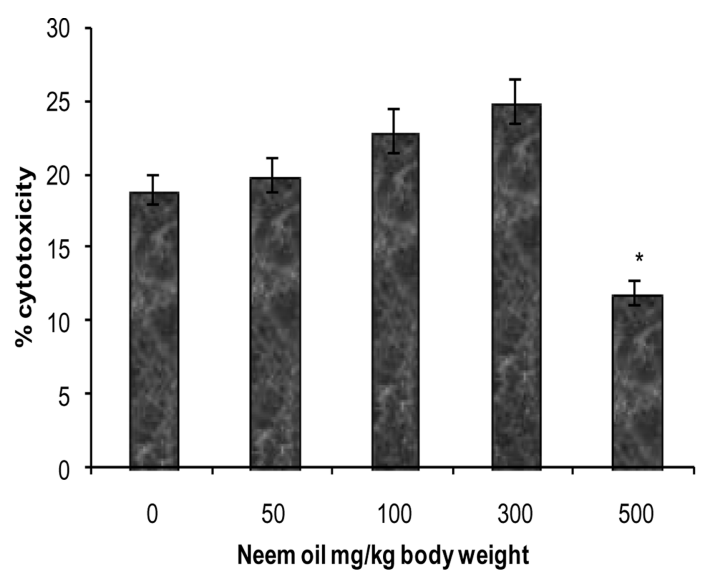

Fig. 3. Effect of neem oil on the activation of TAM to tumoricidal state. TAM obtained from DL-bearing mice administered with neem oil (50, 100, 300, and $500 \mathrm{mg} / \mathrm{kg}$ body weight) or vehicle was cultured in vitro in presence or absence of LPS $(10 \mu \mathrm{g} / \mathrm{ml})$ for $24 \mathrm{~h}$ culture supernatants were harvested for TNF assay. Percent cytotoxicity against L 929 cells was assayed. Values are mean of three independent experiments done in triplicate and are expressed as mean \pm S.D. ${ }^{*} P<0.05$ Vs Values for TAM obtained from mice treated with vehicle or neem oil at lower doses.

$500 \mathrm{mg} / \mathrm{kg}$ body weight of neem oil.

Effect of neem oil on in vitro survival of tumor cells The effect of neem oil on the in vitro survival of tumor cells was estimated by MTT assay. Tumor cells $\left(1 \times 10^{5}\right.$ cells well $\left.^{-1}\right)$ obtained from DL-bearing mice with or without neem oil administration and cell survival was estimated by MTT assay as described in the materials and methods. Results are shown in Fig. 4. It was found that neem oil administration resulted in a signifant augmentation in the survival of DL cells compared to DL cells obtained from mice administered with vehicle alone.

Table 1. Effects of neem oil on percent DNA fragmentation of BMC, splenocytes and thymocytes

\begin{tabular}{ccc}
\hline $\begin{array}{c}\text { Types of } \\
\text { Cells }\end{array}$ & $\begin{array}{c}\text { Vehicle treated (DL-bearing mice) } \\
\text { mean } \pm \text { S.D. }\end{array}$ & $\begin{array}{c}\text { Neem oil (500 mg/kg body weight DL-bearing mice) } \\
\text { mean } \pm \text { S.D. }\end{array}$ \\
\hline BMC & $13.66 \pm 0.53$ & $40.36 \pm 0.46^{*}$ \\
Thymocytes & $18.19 \pm 0.10$ & $21.11 \pm 0.42^{*}$ \\
Splenocytes & $12.13 \pm 1.86$ & $20.14 \pm 0.85^{*}$ \\
\hline
\end{tabular}

${ }^{*} P<0.05$, significantly different from values of respective controls. 


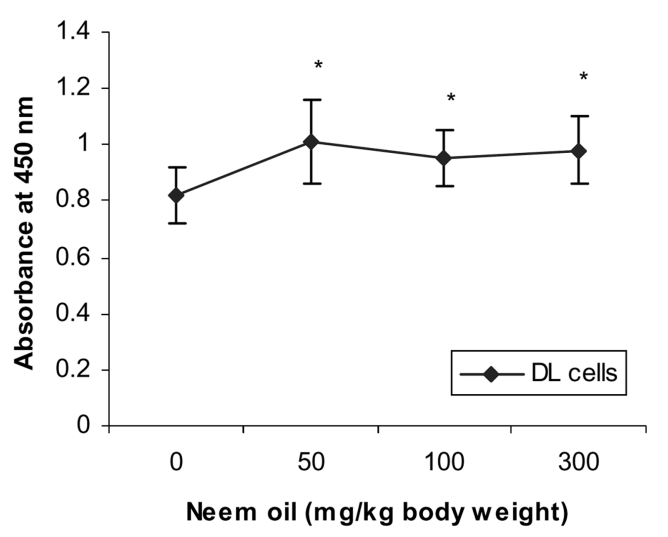

Fig. 4. Effect of neem oil administration on the proliferation of DL cells in vitro. DL cells isolated from DL-bearing mice administered with neem oil at the indicated doses or the same volume of vehicle, following incubation in vitro for estimation of cell survival by MTT assay as described in the materials and methods. Values are mean of three independent experiments done in triplicate and are expressed as mean \pm S.D. ${ }^{*} P<0.05$, significantly different from values of respective controls.

\section{DISCUSSION}

In the present investigation we have studied the effect of neem oil on the progression of a transplantable $\mathrm{T}$ cell lymphoma designated as DL. Neem oil has been shown to have a modulatory effect on the immune system (Upadhyay et al., 1992) and similar nature of immunostimulation was also seen with neem leaf extract (Ray et al., 1996) and neem derived polysaccharides (Fujiwara et al., 1982). Inspite of these findings the effect of neem oil on tumor growth remains neglected. Our investigation is novel and first of its kind. Till date no one has reported the effect of neem oil on progression of any $\mathrm{T}$ cell tumor. Contradictory to the findings of Fujiwara (1982), our observation suggests an increased growth of DL in mice treated with neem oil. Intraperitoneal administration of neem oil was shown to accelerate DL growth and resulted in early death of DL-bearing mice compared to tumor-bearing mice not treated with neem oil.

The inhibition of TNF production by macrophage upon neem oil administration suggests that TAM with a decreased anti-tumor activity may have provided a conducive growth environment for DL cells. Moreover we have earlier reported that TAM contributes directly to the promotion of DL growth (Parajuli and Singh, 1996). The difference of these observations from that of Upadhyay et al. (1992) could be due to the fact that they used normal macrophages which are responsive for activation whereas in the present study we used TAM which we have demonstrated to be in a suppressed state and are unresponsive to activation signals (Parajuli et al., 1997). On the basis of the observations of the present study we suggest that crude neem oil contains some components, which help in progression of DL.

However, it is not clear if neem oil will have similar effects on others tumors as well. An additional cause for accelerated DL growth could be action of neem oil on components of immune system. Indeed we observed that higher doses of neem oil administration resulted in the induction of apoptosis of lymphocytes. Since neem oil has been shown to stimulate $\mathrm{T}$ cell proliferation at optimum dose (Upadhyay et al., 1992) and that DL is itself a T cell tumor, a direct mutagenic effect of neem oil on DL cells may also be a reason for the augmented DL growth on neem oil administration. The possibility that neem oil may have a different action on tumor growth if administered orally or through other route needs to be investigated. In the present study neem oil was administered directly into the peritoneal cavity where DL cells were growing. So the action of neem oil could be a direct one on tumor cells rather than that of its metabolized products.

Despite unsolved problem the results of the present study are of unique significance as they shows that neem oil when administered i.p. to T cell lymphoma bearing host may support tumor growth rather than inhibiting it, as reported with other tumors and will have long lasting clinical applications in designing anticancer therapies with neem oil. 


\section{ACKNOWLEDGEMENTS}

We are grateful to the Department of Biotechnology, Government of India for financial support. Junior research fellowship to Vivekanand from Indian Council of Medical Research, India (Award No. 3/ $1 / 3 / \mathrm{JRF} / 2004$ - MPD) is acknowledged. We are grateful to Prof. Gajendra Singh, Director Institute of Medical Science and Dr. Pandey, In charge, Animal Room Facility, Institute of Medical Sciences, B.H.U. for their help.

\section{REFERENCES}

Bharti A, Singh SM. (2000) Induction of apoptosis in bone marrow cells by gangliosides produced by a T-cell lymphoma. Immunol. Lett. 72, 39-48.

Bharti A, Singh SM. (2001) Gangliosides derived from T-cell lymphoma inhibit bone marrow cell proliferation and differentiation. Int. Immunopharmacol. 1, 155-165.

Bharti A, Singh SM. (2003) Inhibition of macrophage nitric oxide production by gangliosides derived from a spontaneous T-cell lymphoma: the involved mechanism. Nitric Oxide 8, 75-82.

Fujiwara T, Takeda T, Ogihara $\mathrm{Y}$, Shimizu M, Nomura T, Tomita Y.(1982) Studies on the structure of polysaccharides from the bark of Melia azadirachta. Chem. Pharm. Bull. 30, 4025-4030.

Klein G. (1951) comparative studies of mouse tumors with respect to their capacity for growth as 'Ascitic tumors' and their average nucleic acid content. Exp. Cell Res. 2, 518-524.

Koul O, Singh G, Singh R, Daniewski WM, Berlozecki S. (2004) Bioefficacy and mode-of-action of some limonoids of salannin group from Azadirachta indica A. Juss and their role in a multicomponent system against lepidopteran larvae. J. Biosci. 29, 409-416.

Mossman T. (1998) Rapid colorimetric assay for cellular growth and survival. J. Immunol. Methods 65, 53-63.

Parajuli P and Singh SM. (1996) Alteration in IL-1 and arginase activity of tumor-associated macrophages: A role in the promotion of tumor growth. Cancer Lett. 107, 249-256.
Parajuli P, Singh SM, Kumar A, Sodhi A. (1997) Alterations in the tumoricidal functions of murine tumor-associated macrophages during progressive growth of a tumor in vivo. Cancer J. 10, 222-227.

Ray A, Banerjee BD, Sen P. (1996) Modulation of humoral and cell-mediated immune responses by Azadirachtca indica (neem) in mice. Indian J. Exp. Biol. 34, 698-701.

Sellins KS, Cohen JJ. (1987) Gene induction by gammairradiation leads to DNA fragmentation in lymphocytes. J. Immunol. 139, 199-206.

Singh N, Singh SM, Srivastava P. (2004) Immunomodulatory and antitumor action of medicinal plant Tinospora cordifolia are mediated through activation of tumor-associated macrophages. Immunopharmacol. Immunotoxicol. 26, 145-162.

Singh N, Singh SM, Prakash, Singh G. (2005) Restoration of thymic homeostasis in a tumorbearing host by in vivo administration of medicinal herb Tinospora cordifolia. Immunopharmacol. Immunotoxicol. 27, 585-599.

Singh N, Singh SM, Srivastava P. (2005) Effect of Tinospora cordifolia on the anti-tumor activity of tumor-associated macrophages-derived dendritic cells. Immunopharmacol. Immunotoxicol. 27, 1-14.

Singh MP, Rai AK, Singh SM. (2005) Gender dimorphism in the progressive in vivo growth of a T cell lymphoma: involvement of cytokines and gonadal hormones. J. Reprod. Immunol. 65, 17-32.

Singh MP, Singh G, Singh SM. (2005) Role of host's antitumor immunity in exercise-dependent regression of murine T-cell lymphoma. Comp. Immunol. Microbiol. Infect. Dis. 28, 231-248.

Singh SM, Singh N, Srivastava P. (2006) Effect of alcoholic extract of Ayurvedic herb 'Tinospora cordifolia' on the proliferation and myeloid differentiation of bone marrow precursor cells in a tumor-bearing host. Fitoterapia 77, 1-11.

Singh MP,Sharma H, Singh SM. (2006) Prolactin promotes growth of a spontaneous T-cell lymphoma: Role of Tumor and Host derived Cytokines. Cancer Invest. 24, 601-610.

Upadhyay SN, Dhawan S, Garg S, Talwar GP. (1992) Immunomodulatory effects of neem (Azadirachta indica) oil. Int. J. Immunopharmacol. 14, 1187-1193. 